\title{
The safety and efficacy of feracrylum as compared to silver sulfadiazine in the management of deep partial thickness burn: A clinical study report
}

\author{
Yefta Moenadjat, ${ }^{1}$ Rianto Setiabudy, ${ }^{2}$ Dalima AW Astrawinata, ${ }^{3}$ Saukani Gumay ${ }^{4}$
}

\begin{abstract}
Abstrak
Feracrylum merupakan obat topikal yang mengandung garam besi poliakrilat 0.05 sampai $0.5 \%$. Obat ini terbukti memiliki efek antibakteri dan efektif untuk mengobati luka bakar. Suatu uji klinik tentang efektivitas dan keamanan dari feracrylum dibandingkan dengan silver sulfadiazin (SSD) telah dilakukan pada penderita luka bakar, dengan metode studi terbuka, acak, berpembanding. Feracrylum dan SSD dioleskan tiap hari pada masing-masing satu sisi badan dan hasilnya diobservasi selama 11 hari. Tujuh dari 8 pasien dapat menyelesaikan studi ini. Pada hari 7 dan 11 reepitelisasi meningkat pada sisi tubuh yang mendapat feracrylum yang terlihat dengan berkurangnya luas lesi. Persentase epitelisasi pada kelompok feracrylum adalah $70.53 \pm 24.298$ dan $81.71 \pm 28.922 \%$ pada hari ke-7 dan

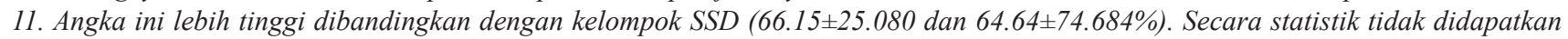
perbedaan yang bermakna. Feracrylum terbukti aman dan dapat ditoleransi dengan baik. (Med J Indones 2008; 17: 259-71)
\end{abstract}

\begin{abstract}
Instead of haemostatic effect, feracrylum provides antibacterial activity; wound improvement has been clinically proven. Feracrylum is a water soluble mixture of incomplete ferrous salt of polyacrylic acid containing 0.05 to $0.5 \%$ of iron in physiologic solution (0.85\% solution of sodium chloride). A clinical study on safety and efficacy of feracrylum compared to silver sulfadiazine (SSD) was conducted in burn management, since with the widely use of SSD, the sulfadiazine's disadvantages lead to wound healing impairment. In this open, randomized, controlled study, feracrylum and SSD were topically applied, each on different side of the burnt areas in parts of body for a treatment period of eleven days. Of eight enrolled patients, seven patients completed the study; one patient withdrew due to acute burn complication. On day $7^{\text {th }}$ and $11^{\text {th }}$, the re-epithelialization in group receiving feracrylum increased as the raw surface area reduced. Mean percentages of epithelialization on both evaluation days in Feracrylum group were $70.53 \pm 24.298$ and $81.71 \pm 28.922$, respectively, which were higher than SSD group (66.15 \pm 25.080 and $64.64 \pm 74.684$ respectively). Feracrylum was found to be safe and well tolerated. This study showed a clinical difference although it was not significant statistically. (Med J Indones 2008; 17: 259-71)
\end{abstract}

Keywords: Feracrylum, silver sulfadiazine, wound management

Burn is a devastating injury since there are too many encountered problems, including wound healing. Focused on the wound management, for at least twenty

1 Department of Surgery, Faculty of Medicine, University of Indonesia/Dr. Cipto Mangunkusumo Hospital, Jakarta, Indonesia

2 Department of Pharmacology, Faculty of Medicine, University of Indonesia, Jakarta, Indonesia

3 Department of Clinical Pathology, Faculty of Medicine, University of Indonesia/Dr. Cipto Mangunkusumo Hospital, Jakarta, Indonesia

4 Department of Anatomical Pathology, Faculty of Medicine, University of Indonesia, Jakarta, Indonesia years, silver-containing preparations have been known to have superior antimicrobial characteristics and successfully decreasing the incidence of burn sepsis. ${ }^{1-9}$ These features are likely associated with the high microbial killing rate of the silver and minimal incidence of resistance reported. ${ }^{6}$ Therefore the application of silver sulfadiazine becomes standard therapy in burn treatment. The major disadvantages of these agents include the instability, light sensitivity, as well as silver toxicity. To overcome these problems, several components have been coupled with silver (e.g. nitrate and sulfadiazine). ${ }^{6}$ Along with the world-wide use of these silver-containing preparations (particularly silver sulfadiazine, SSD), many clinical problems have been 
also been encountered. For instances, painful dressing change, eschar pigmentation that mimicking wound infection, delayed wound healing due to production of proteases (e.g. metalloproteinase) that unexpectedly propagating inflammatory process. ${ }^{6,-13}$ Nevertheless, these unsatisfactory clinical experiences were minimally published. Further, such a circumstance has prompted the researchers to develop a new approach in burn management, including the so-called "Local Haemostatic Antimicrobial topical solution" (i.e. feracrylum).

Feracrylum is a water soluble mixture of incomplete ferrous salt [II, III] of polyacrylic acid containing 0.05 to $0.5 \%$ of iron in combination with the pharmaceutical solvent which is water or physiologic solution ( $0.85 \%$ solution of sodium chloride) the active principle content being $1-2 \%$ by $w / v$. Feracrylum is obtained by polymerization of acrylic acid inhibited by redoxsystem in aqueous medium at $50^{\circ} \mathrm{C}$ temperature. Feracrylum is in the form of glass like yellowish brown flakes. It is soluble in water, but not in organic solvents. The ready medicinal preparation of $1 \%$ aqueous solution has sour taste ( $\mathrm{pH}$ 2.9-4.0) and is odourless. Feracrylum and its solutions withstand sterilization at temperature of $120^{\circ} \mathrm{C}$ and pressure of 1.5 atmospheres. Sterile aqueous solutions of the preparation are stable for a period of 2 or more years. Relative viscosity of $1 \%$ solution of feracrylum in comparison with water is 2.0-5.5 with molecular weight of 500,000-800,000 Dalton.

The mechanism of action of feracrylum is by the forming water insoluble multi-complexes with various proteins, including those contained in blood. Being an acidic polyelectrolyte, the preparation is highly active at $\mathrm{pH}$ 2.9-4. Due to the property of non specific coagulation between feracrylum and blood proteins, this preparation may be used to stop the bleeding through interfering the coagulation system as in haemophilia as well as in over dosage of anticoagulants administration. This was effective as feracrylum does not interfere with blood clotting process mechanism, neither with any steps in the normal coagulation process. The haemostatic effect of feracrylum is provided by the formation of a synthetic complex consisting of it's adduct with plasma proteins principally albumin on the wound surface. Large rubbery clot is formed as the solution of feracrylum and serum albumin mixed in-vitro. Like any other biodegradable polymers the feracrylum-albumin complex is broken down over a period of time. These subunits are excreted after then.
Feracrylum has a wide range of antimicrobial activity against both Gram positive and Gram negative microorganisms. ${ }^{14}$ The observed antimicrobial activity of feracrylum makes it a very valuable haemostatic preparation in antiseptic condition viz. in industrial and domestic trauma, preoperative surgical preparation, suppuration of wounds, and irrigation of infected bleeding wounds, diabetic ulcers, haemorrhoids, secondary suturing and any other infected site requiring surgical haemostasis. In the presence of antimicrobialresistant strains of microorganism is one of the common reasons for the incidence of purulent-septic complications. The use of antibiotics for prevention of chronic infection foci has many short comings due to low sensitivity of microbes to the antibiotics and possibility of emerging new antibiotic resistant strains. The merit of feracrylum lies on its combination of the antimicrobial activity having no toxicity nor local-irritating action; let it applicable in prevention of acute, chronic and hospital infection particularly post operative wounds; thus, promoting wound recovery.

The effects of bacteriostatic, bactericidal and mycostatic of the drug were studied on a spectrum of 13 strains of microorganisms. It was observed that feracrylum $1 \%$ indicates a remarkable activity against Staphylococcus aureus, E. coli and the fungi C. albicans with complete elimination of viable count in 2 hours. Feracrylum provides an optimal environment that facilitates wound healing, decreases the rate of wound infection, and appears to be the trend of wound management in the future. ${ }^{15-22}$

As feracrylum is proven through phases in the trial to be a good antiseptic and haemostatic agent, the use in burn management referred to remain scanty.

The aim of this study is to see the safety and efficacy of feracrylum in burn management, particularly in deep partial thickness burn that subjected to spontaneous reepithelialization. In this study, we compared feracrylum (attributed to treatment) to SSD (as the "standard topical application' in burn treatment, attributed to control). The hypothesis of interest in this study was healing rate in deep partial thickness (deep second degree) burn treated with feracrylum is shorter than SSD and the prevalence of wound infection treated with feracrylum is lesser than SSD treated. 


\section{METHODS}

This was an open blinded and randomized controlled study. ${ }^{23}$ The population was burned victims (male and female) admitted in Burn unit RSCM Hospital who were diagnosed partial thickness burn (second degree of burn) with symmetrical distribution in the part of body and wound of more than $10 \mathrm{~cm}$ in diameter. The inclusion-criteria were those of more than 1 year old. Should there clinically detected signs of critical burn (shock, inhalation injury with or without respiratory distress) then the case would be excluded. Pregnancy, women in child bearing period and patient with history of hypersensitivity to feracrylum and/or SSD would be excluded as well.

The distribution of burnt lesion should be more or less symmetrical in any part of the body. Feracrylum 1\% solution, as the test-drug and silver sulfadiazine (SSD) $1 \%$ cream, as standard-control drug, were randomly allocated to each site (either left or right) of the body. In patients with a single lesion, the lesion was divided in three equal parts along its longitudinal axis; feracrylum and SSD were randomly applied to each opposite end parts of a lesion and plain gauze was applied in the middle as a divider to prevent interference of one to another side. Both feracrylum and SSD cream were topically applied following wound toilet and both of treated wounds are then dressed with tulle grass and sufficient-thickness adsorbent gauze. Dressing change was carried out every two consecutive days. The wounds were subject to evaluation up to eleven day.

A routine blood examination was carried out on the $1^{\text {st }}$ day of trial (baseline), and the Day-7. These laboratory data which consisted of hematology test, i.e. hemoglobin content $(\mathrm{Hb})$, Hematocryte $(\mathrm{Ht})$, white blood cells (WBC), platelet count and blood chemistry: serum glutamic oxaloacetic transaminase (SGOT), serum glutamic pyruvate transaminase (SGPT), blood urea nitrogen (BUN), creatinine, level of serum glucose and serum albumin, were all required to assess the safety of study treatment.

These subjects were monitored for signs and symptoms of adverse event at every study visit. Should there any adverse reaction, the subject was withdrawn from the study and promptly treated for the adverse reaction. All adverse events were recorded in the case report form (CRF).

Clinical evaluations were made at baseline (day 0), day 3, day 5, day 7, day 9 and day 11 of the study. The endpoint of primary efficacy was the percentage of epithelial-covered of raw surface (on day-7 and day-11 of study, respectively); this was reflected by reduction of the raw surface in size (centimeter square).

To achieve accurate wound measurement in the evaluation of wound size, the raw surface was calculated in such a manner as shown in figure 1.

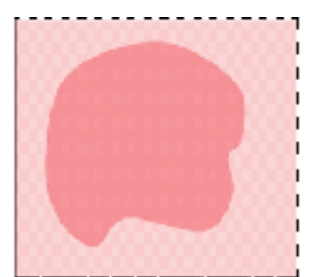

a

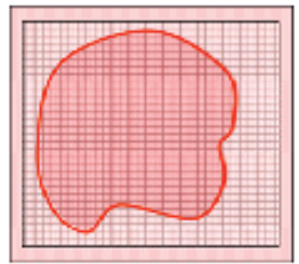

A.

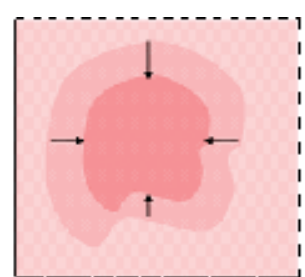

5

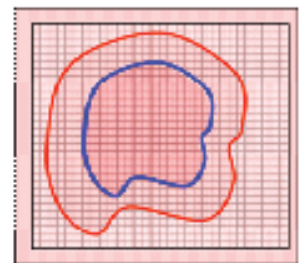

Fy

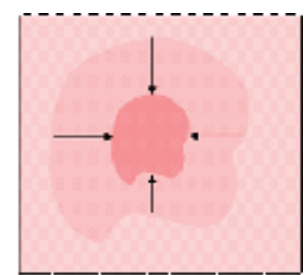

s.:

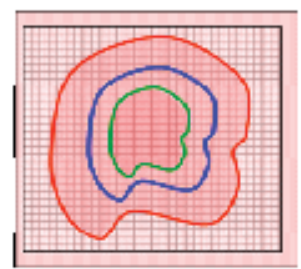

$\because$

Figure 1. Wound measurement method. Above: initial raw surface (A) reduced in size $(B, C)$ as the process of re-epithelialization proceeded. Below: initial size of raw surface was outlined using red-colour permanent ink drawn in gridline transparent sheet on day 0 of the trial (A). The wound measured on day 7 (B) using blue-colour permanent inks drawn in a different transparent sheet provided, and green-colour permanent ink on day 11 of the trial $(C)$. The use of different sheet in each drawn was to avoid investigator's subjectivity due to conflict of interest. The size of raw surface was calculated using Visitrak ${ }^{\circledR}$ (Smith and Nephew, USA); reduction of raw surface reflecting re-epithelialized area. 
The infection was the next parameter subject to evaluation in this study. Clinically, the evidence of infection is observed and recorded on baseline and every following two days throughout the 11 day of the study. A patient was attributed to have infection clinically if these below criteria meet: 1) increased intensity of pain in burnt area, (2) inflammation (swelling and reddening) of burnt area, (3) pus formation and (4) fever. The criteria of infection met if at least 3 of 4 symptoms were noted. To obtain the information of bacteriological pattern available on the wound surface, a serial bacteriological examinations were carried out using swab method on baseline (day 0) and day 7 of the study.

The characteristic of wound bed as well as objective sign of epithelialization is obtained by histopathology examination performed on the day 0 and day 11 .

Pain was evaluated during change dressing using WongBaker faces pain rating scale ${ }^{\mathrm{i}}$ (pain intensity rating scale, PIRS) and recorded in the CRF. In case of patient with a single lesion, the pain intensity measurement of each treatment group was impossible to be evaluated separately.

All collected data in this study was tabulated and analyzed for the Intention-to-treat (ITT) population. Percentage of re-epithelialization and raw surface area were both statistically analyzed by independent-t-test; while pain intensity rating scale (PIRS) by Mann-
Whitney-U-test. These data is processed with SPSS ver.12.0 software program and all statistical analysis is at $5 \%$ significance level (2-tailed); using chi square test, whereas $\mathrm{p}<0.05$ is significant.

The study was approved by the institutional review board and all clinical investigations were conducted in accordance to the Declaration of Helsinki and Good Clinical Practice (GCP). Written informed consent was obtained from all patients who agreed to participate in the study.

Enrolled patients were assigned to receive study treatment based on random numbers provided by the sponsor.

\section{RESULT}

Eight admitted patients were enrolled with informed consent in the burn unit of RSCM Hospital as the subjects of this study. The study started on August 2005 and completed on December 2006. All patients were treated with feracrylum and SSD on each different side of the body. The overall patient disposition is summarized below in figure 1 . Of the enrolled 8 patients, 1 patient was withdrawn; died due to respiratory distress as a complication of acute burn injury. There was no after treatment data for this withdrawn patient, therefore the assessment of efficacy on this patient was not conducted.

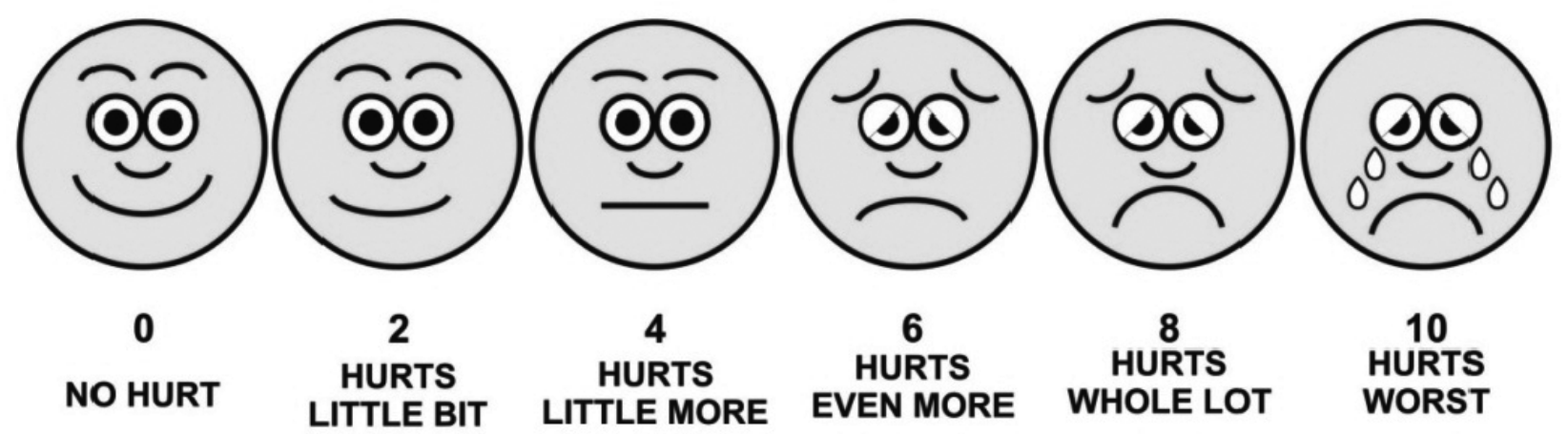

Figure 2. Wong-Baker faces pain rating scale

${ }^{i}$ Downloaded from website: http://painconsortium.nih.gov/pain_scales/Wong-Baker_Faces.pdf 


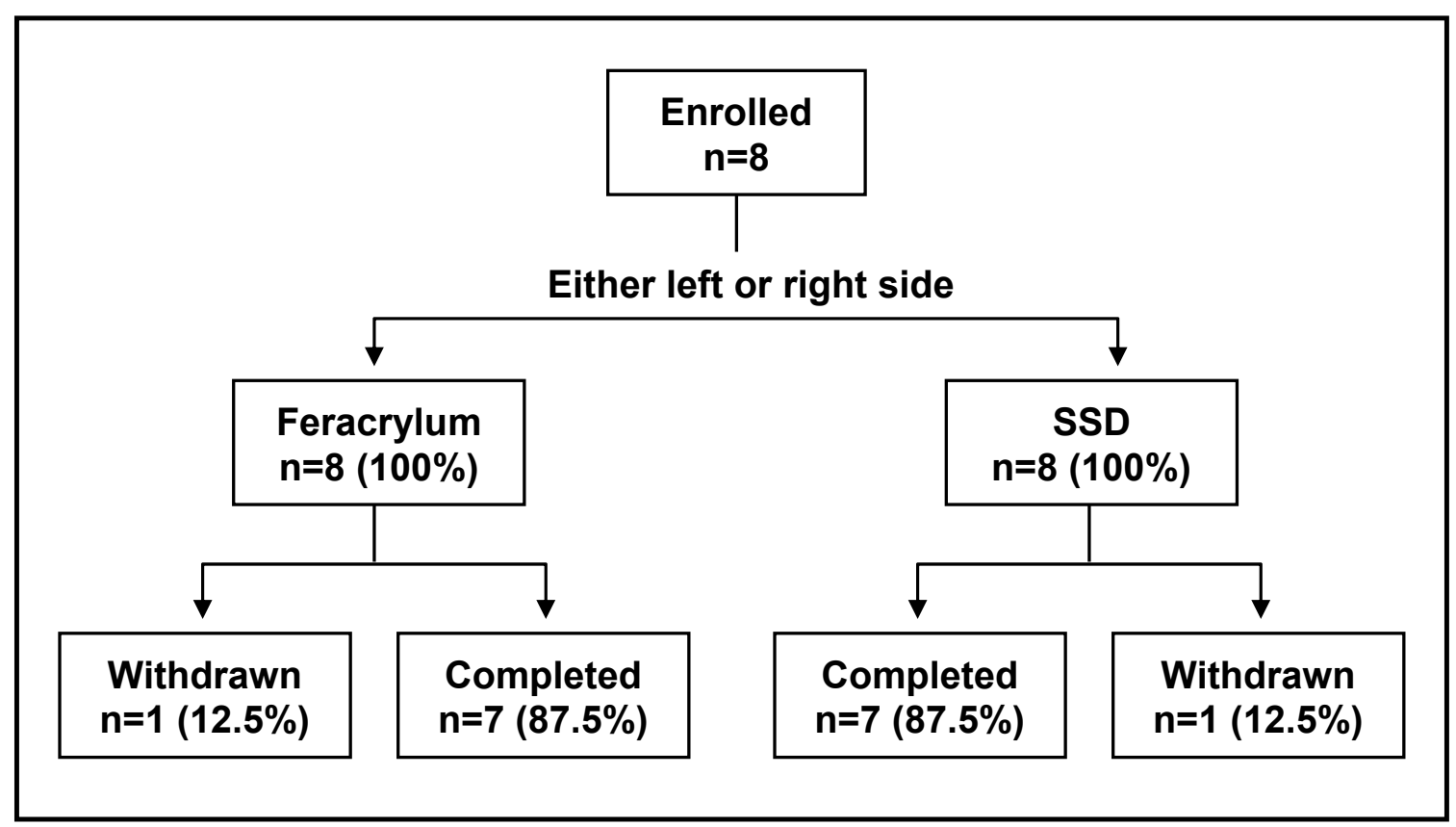

Figure 3. Flowchart indicates the progress of patients enrolled in the study

The study population was at least middle-aged, with higher numbers of female than male. Demographic and baseline characteristics of the subjects in this study were summarized in table 1.

The safety of feracrylum was analyzed based on the information of all patients who had been exposed to - at least a dose of administration of - feracrylum as the trial product. This was descriptively evaluated on all occurring adverse events during the conduct of the study, and examinations of laboratory findings measured at baseline (day 0 ) and day 7 . There was 1 (one) adverse event (dyspnea-respiratory distress) reported in one patient as it previously described. This adverse event resulted in death and was recorded as a severe adverse event (SAE). Platelet count of all subjects increased on day 7 compared to baseline. The complete laboratory finding is tabulated in Table 1.

In the evaluation of the efficacy use of feracrylum, we found that feracrylum provided a greater size reduction of raw surface (higher percentage of re-epithelialized area) but in further analysis we found that such difference between two groups was not statistically significant (Figure 4 and Table 2). The mean raw surface area measured in the feracrylum group and SSD groups were $38.38 \pm 23.961 \mathrm{~cm}^{2}$ and $38.52 \pm 21.738 \mathrm{~cm}^{2}$, respectively.

We observed that the re-epithelialization in the two groups was achieved although these subjects in both of the two groups were exposed to bacterial population found i.e. Pseudomonas sp, Klebsiella pneumoniae, Staphylococcus epididimis, Enterobacter aerogenes, Bacillus sp and Acinobacter calcoaceticus which are the common populations found in burnt area as well as any other wound (Table 4). In fact, during the 11 days period of the trial, not a single patient experienced sign of infection clinically. We found that qualitative (bacterial strain) and quantitatively (the amount of bacterial population); the difference between two groups was not significant. 
Table 1. Demographic and baseline characteristics of the patients in the two groups

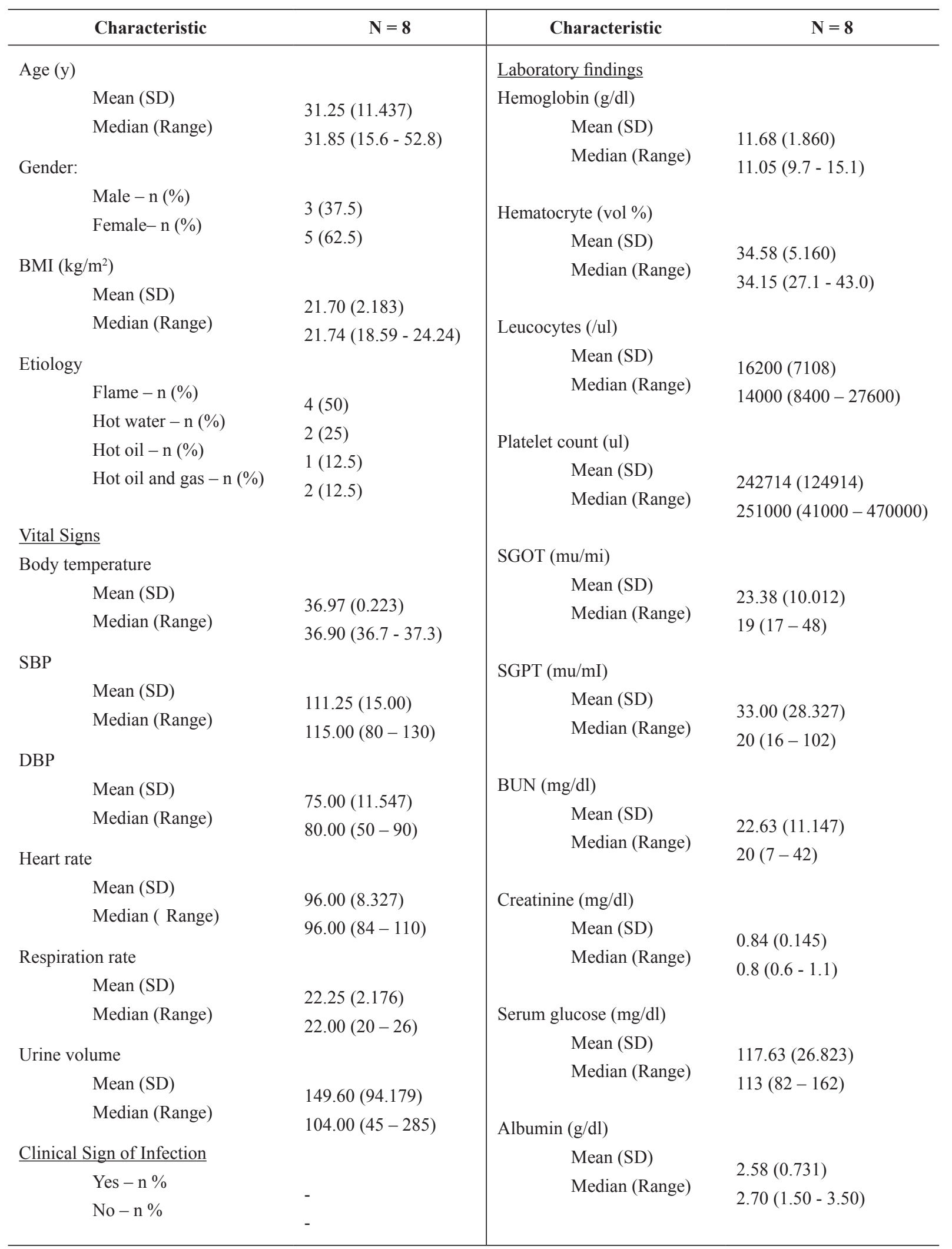


Table 2. Different characteristic of the patients

\begin{tabular}{|c|c|c|c|}
\hline Characteristic & Ferracrylum $(n=8)$ & $\operatorname{SSD}(n=8)$ & p value \\
\hline \multicolumn{4}{|l|}{ PIRS } \\
\hline No pain - $\mathrm{n} \%$ & $2(25)$ & $1(12.5)$ & N/A \\
\hline Pain Little Bit $-\mathrm{n} \%$ & $3(37.5)$ & $1(12.5)$ & \\
\hline Pain Little More $-\mathrm{n} \%$ & $3(37.5)$ & $3(37.5)$ & \\
\hline Pain Even More - n \% & - & $3(37.5)$ & \\
\hline Pain Whole Lot $-\mathrm{n} \%$ & - & - & \\
\hline Pain $-\mathrm{n} \%$ & - & - & \\
\hline \multicolumn{4}{|l|}{ Raw Surface Area $\left(\mathrm{cm}^{2}\right)$} \\
\hline Mean (SD) & $38.38(23.961)$ & $38.52(21.738)$ & 0.991 \\
\hline Median & 35.30 & 36.40 & \\
\hline Range & $7.90-85.20$ & $7.50-71.10$ & \\
\hline
\end{tabular}

Legend:

BMI, Body Mass Index, SBP, Systolic Blood Pressure; DBP, Diastolic Blood Pressure;

PIRS, Pain Intensity Rating Scale; SGOT, Serum Glutamic Oxaloacetic Transaminase;

SGPT, Serum Glutamic Pyruvate Transaminase

Table 3. The efficacy of treatment

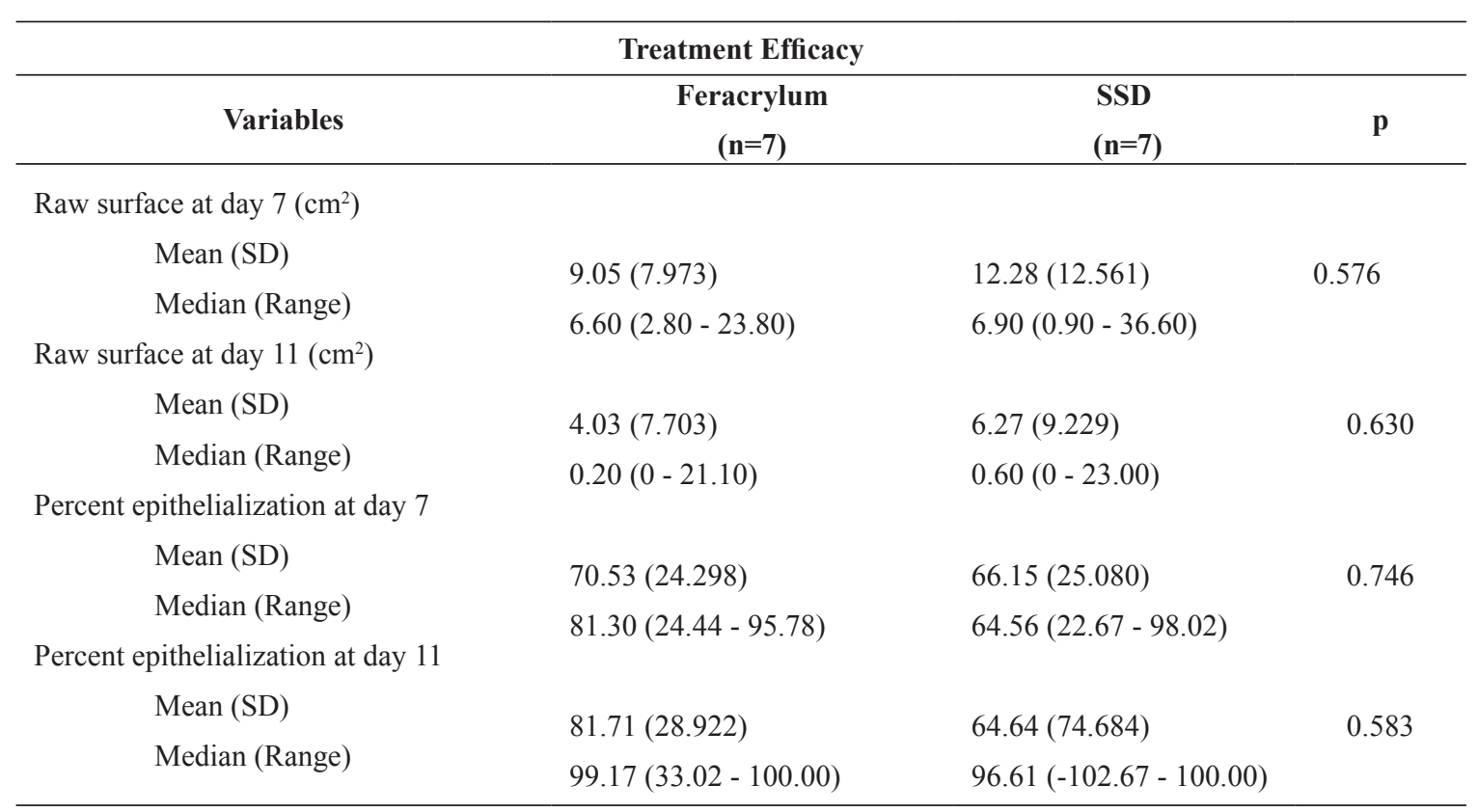



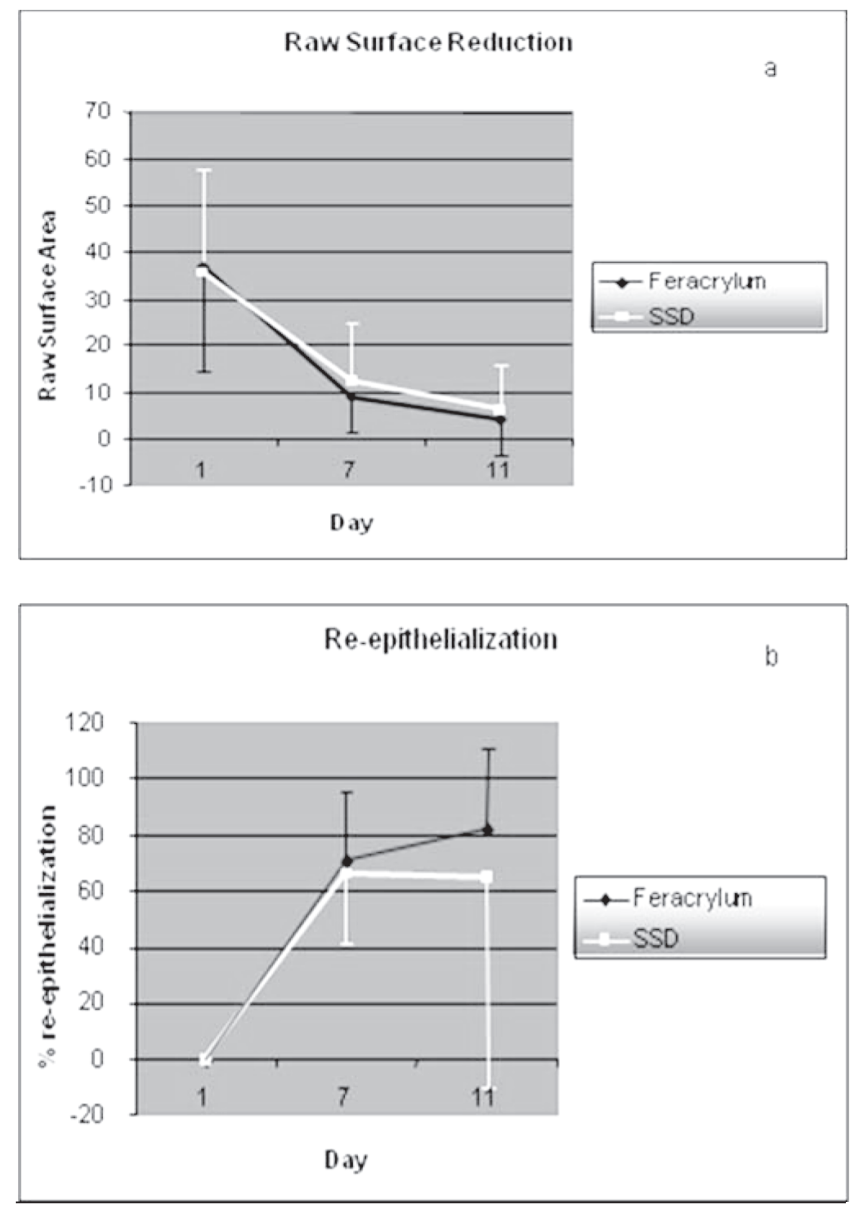

Figure 4. Percent of raw surface reduction (a) and re-epithelialized area (b) on day-7 and day-11

Table 4. Bacterial examination

\begin{tabular}{|c|c|c|c|c|}
\hline \multicolumn{5}{|c|}{ Bacteriological Examination } \\
\hline \multirow{3}{*}{ Microorganism } & \multicolumn{4}{|c|}{ Number of exposed subjects } \\
\hline & \multicolumn{2}{|c|}{ Day 1} & \multicolumn{2}{|c|}{ Day 7} \\
\hline & Fer $(n=8)$ & $\operatorname{SSD}(\mathbf{n}=8)$ & Fer $(n=7)$ & $\operatorname{SSD}(n=7)$ \\
\hline Pseudomonas sp & 6 & 5 & 4 & 4 \\
\hline Klebsiella pneumoniae & 1 & 1 & 1 & 1 \\
\hline Staphylococcus epididimis & 1 & 1 & 1 & 1 \\
\hline Enterobacter aerogenes & - & 2 & - & - \\
\hline Staphylococcus aureus & - & - & 1 & - \\
\hline Basillus sp & - & - & 1 & - \\
\hline Acinetobacter calcoaceticus & - & - & - & 1 \\
\hline
\end{tabular}

Note: one subject could be possibly infected by more than one microorganism. 
The histopathology examination showed insufficient data, as the patients refused to carry out the procedure of biopsy. The only exam obtained from a patient show the characteristics of acute inflammation with no difference between the two treatments on the day 0 .
The pain intensity rating scale (PIRS) indicated that the pain intensity during change dressing in consequent two days was comparable between feracrylum and SSD group (table 5).

Table 5. The evaluation of pain

Pain Intensity Rating Scale (PIRS)

\begin{tabular}{|c|c|c|c|c|}
\hline \multicolumn{5}{|c|}{ Pain Intensity Rating Scale (PIRS) } \\
\hline & Criteria & Feracrylum $(n=8)$ & $\operatorname{SSD}(n=8)$ & $\mathbf{p}$ \\
\hline \multicolumn{5}{|l|}{ Day 1} \\
\hline & No pain $-\mathrm{n} \%$ & - & - & \\
\hline & Pain little bit $-\mathrm{n} \%$ & - & $1(12.5)$ & \\
\hline & Pain little more $-\mathrm{n} \%$ & $2(25)$ & $1(12.5)$ & 0.959 \\
\hline & Pain even more $-\mathrm{n} \%$ & $3(37.5)$ & $3(37.5)$ & \\
\hline & Pain whole lot $-\mathrm{n} \%$ & $3(37.5)$ & $3(37.5)$ & \\
\hline & Pain worst $-\mathrm{n} \%$ & - & - & \\
\hline \multicolumn{5}{|c|}{ 10 } \\
\hline & No pain $-\mathrm{n} \%$ & $1(12.5)$ & $1(12.5)$ & \\
\hline & Pain little bit $-\mathrm{n} \%$ & $1(12.5)$ & $1(12.5)$ & \\
\hline & Pain little more $-\mathrm{n} \%$ & $2(25.0)$ & $2(25.0)$ & 0.959 \\
\hline & Pain even more $-\mathrm{n} \%$ & $2(25.0)$ & $2(25.0)$ & \\
\hline & Pain whole lot $-\mathrm{n} \%$ & $2(25.0)$ & $1(12.5)$ & \\
\hline & Pain worst $-\mathrm{n} \%$ & - & $1(12.5)$ & \\
\hline \multicolumn{5}{|l|}{ Day 5} \\
\hline & No pain $-\mathrm{n} \%$ & $1(12.5)$ & $3(37.5)$ & \\
\hline & Pain little bit $-\mathrm{n} \%$ & $3(37.5)$ & - & \\
\hline & Pain little more $-\mathrm{n} \%$ & $1(12.5)$ & $4(50)$ & 0.456 \\
\hline & Pain even more $-\mathrm{n} \%$ & $2(25.0)$ & - & \\
\hline & Pain whole lot $-\mathrm{n} \%$ & - & $1(12.5)$ & \\
\hline & Pain worst $-\mathrm{n} \%$ & $1(12.5)$ & - & Pain worst - n \% \\
\hline & No pain - $\mathrm{n} \%$ & $3(37.5)$ & $3(37.5)$ & \\
\hline & Pain little bit $-\mathrm{n} \%$ & $2(25.0)$ & $1(14.3)$ & \\
\hline & Pain little more $-\mathrm{n} \%$ & $2(25.0)$ & $3(37.5)$ & 1.000 \\
\hline & Pain even more $-\mathrm{n} \%$ & - & $1(12.5)$ & \\
\hline & Pain whole lot $-\mathrm{n} \%$ & - & - & \\
\hline & Pain worst $-\mathrm{n} \%$ & $1(12.5)$ & - & \\
\hline \multicolumn{5}{|l|}{ Day 9} \\
\hline & No pain $-\mathrm{n} \%$ & $3(37.5)$ & $3(37.5)$ & \\
\hline & Pain little bit $-\mathrm{n} \%$ & $2(25.0)$ & $2(25.0)$ & \\
\hline & Pain little more $-\mathrm{n} \%$ & $2(25.0)$ & $3(37.5)$ & 0.710 \\
\hline & Pain even more $-\mathrm{n} \%$ & - & - & \\
\hline & Pain whole lot $-\mathrm{n} \%$ & - & - & \\
\hline & Pain worst $-\mathrm{n} \%$ & $1(12.5)$ & - & \\
\hline \multicolumn{5}{|c|}{ Day 11} \\
\hline & No pain $-\mathrm{n} \%$ & $4(50)$ & $3(37.5)$ & \\
\hline & Pain little bit - n \% & $4(50)$ & $3(37.5)$ & \\
\hline & Pain little more $-\mathrm{n} \%$ & - & $2(25.0)$ & 0.535 \\
\hline & Pain even more $-\mathrm{n} \%$ & - & - & \\
\hline & Pain whole lot $-\mathrm{n} \%$ & - & - & \\
\hline & Pain worst $-\mathrm{n} \%$ & - & - & \\
\hline
\end{tabular}




\section{DISCUSSION}

The deep partial thickness burn is subject to spontaneous healing (re-epithelialization); since there is still intact dermal layer left as well as survived integuments. The management of this kind of injury is mostly conservative following the removal of non-vital tissue (eschar removal). The conservative treatment is to provide of a suitable environment which is conducive to let the process of re-epithelialization proceeded in a natural manner. The best environment is free from bacterial contamination - with no infection in particular in spite of warm, moist and well vascularised tissue.

The number of subjects recruited in this study was too small to produce enough statistical power to detect a significant difference between the treatment (feracrylum) and control groups (SSD). As there were only 8 subjects enrolled and of that there were only 7 evaluable subjects. One patient was withdrawn due to a severe complication of acute burn injury that resulted in death. Nevertheless, the overall result of the present study showed a favorable result on patients treated with feracrylum as compared to that treated with SSD.

In this study, the presence of granulation tissue observed as firm and pale tissue (termed as "healthy granulation tissue") was set as the target of therapy and this was suitable to indicate the process of epithelialization. Primary efficacy endpoint of this study was feracrylum ability to promote healing process in deep partial thickness burn, measured as re-epithelialization of the raw surface area. At baseline, raw surface area was comparable between groups (Table 3). On day 7 it was observed that subjects in feracrylum-treated group had a greater mean percentage of re-epithelialization $(70.53 \pm 24.298)$ as the raw surface was getting smaller compared to SSD group $(66.15 \pm 25.080)$. An even greater difference mean value of re-epithelialization between the two groups was observed on day 11 (81.71 \pm 28.922 and $64.64 \pm 74.684$, in feracrylum and SSD group, respectively).

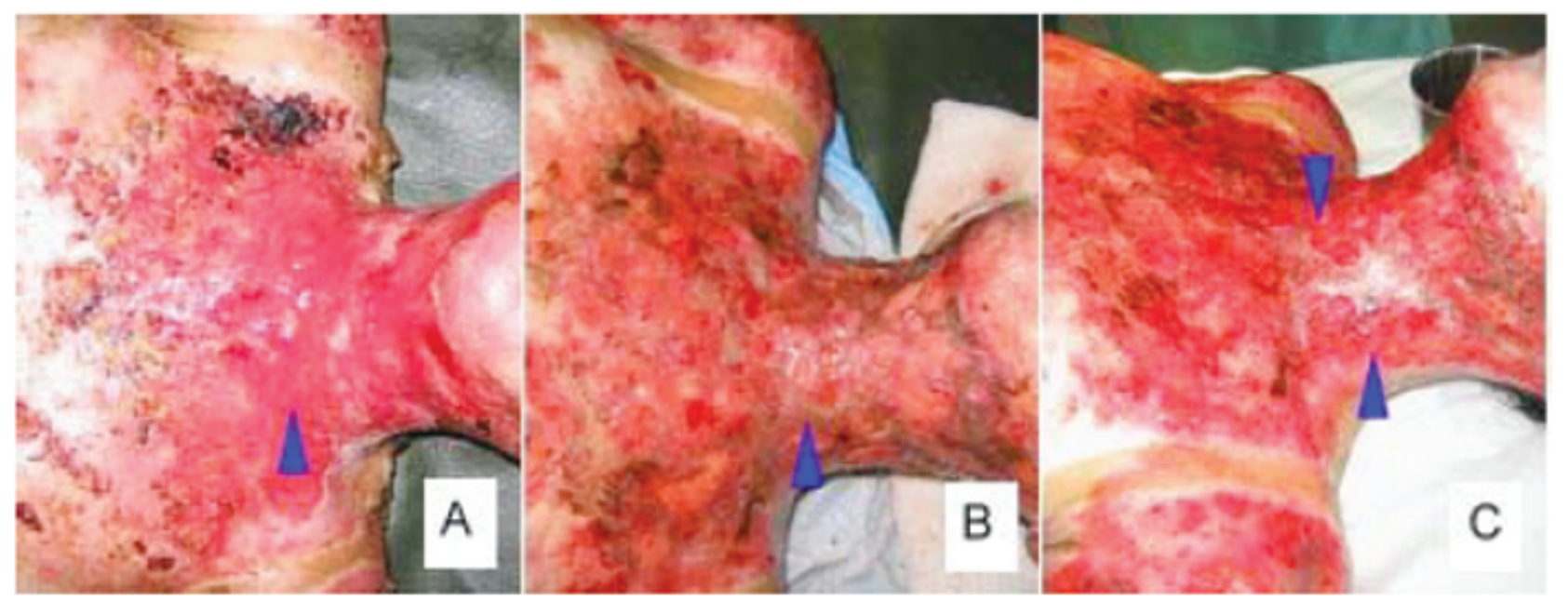

Figure 5. The pictures showing wound in the phase of fibroplasias. A. Unhealthy granulation tissue (arrow indicated) which, exudative is not suitable for graft to take. This kind of wound was formerly treated using SSD. Following skin grafting procedure (B arrow indicated), the grafts were not survived and became expectedly lysis (C, arrow indicated). 


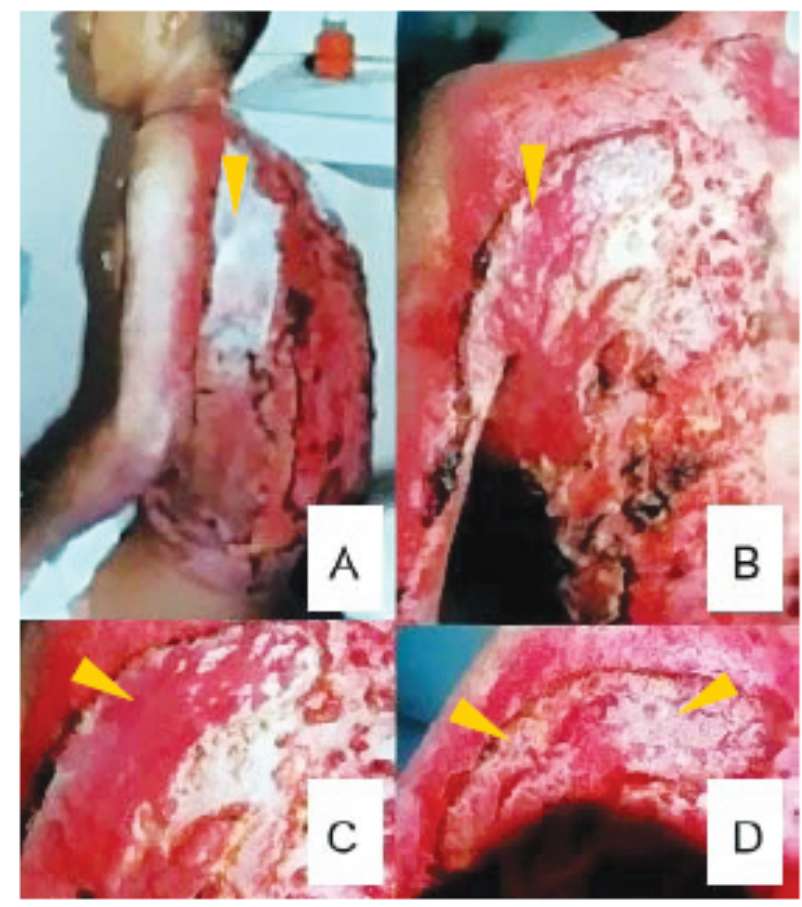

Figure 6. A. Subject with burn injury (flame) in the posterior trunk treated with feracrylum, $B$ and $C$ initial raw surface and D. Re-epithelialization process was preceded on day 11 of the trial.
Such differences were not statistically-powered enough to be significant, however (Table 3). Thus, further larger study is needed to confirm the benefit of feracrylum over the SSD. Yet, such differences of re-epithelialization area between both groups were clinically significant indeed. Such greater re-epithelialization in feracrylumtreated area indicates a better trend toward feracrylum in the treatment of partial thickness burn. This trial result is in line with that of a previous clinical study evaluating the efficacy and safety of feracrylum for dressing burn and other partial thickness wounds. ${ }^{24}$ In the former trial conducted by Patel et.al involving 109 subjects suffered from wounds, chronic non-healing ulcers, burns, wounds $<10 \% \mathrm{BSA}$, and post-operative infected wounds demonstrated a greater percentage of improvement in condition of wound and peripheral edema in those treated with feracrylum compared to those with povidone-iodine. ${ }^{24}$

There was no significant difference in bacterial examination results on patients in both groups (Table 3) since both of feracrylum and SSD are known to have antimicrobial activity..$^{14,25,26}$ In this study we were not able to observe whether feracrylum exerted more potential antimicrobial effect than SSD due to insufficient data.

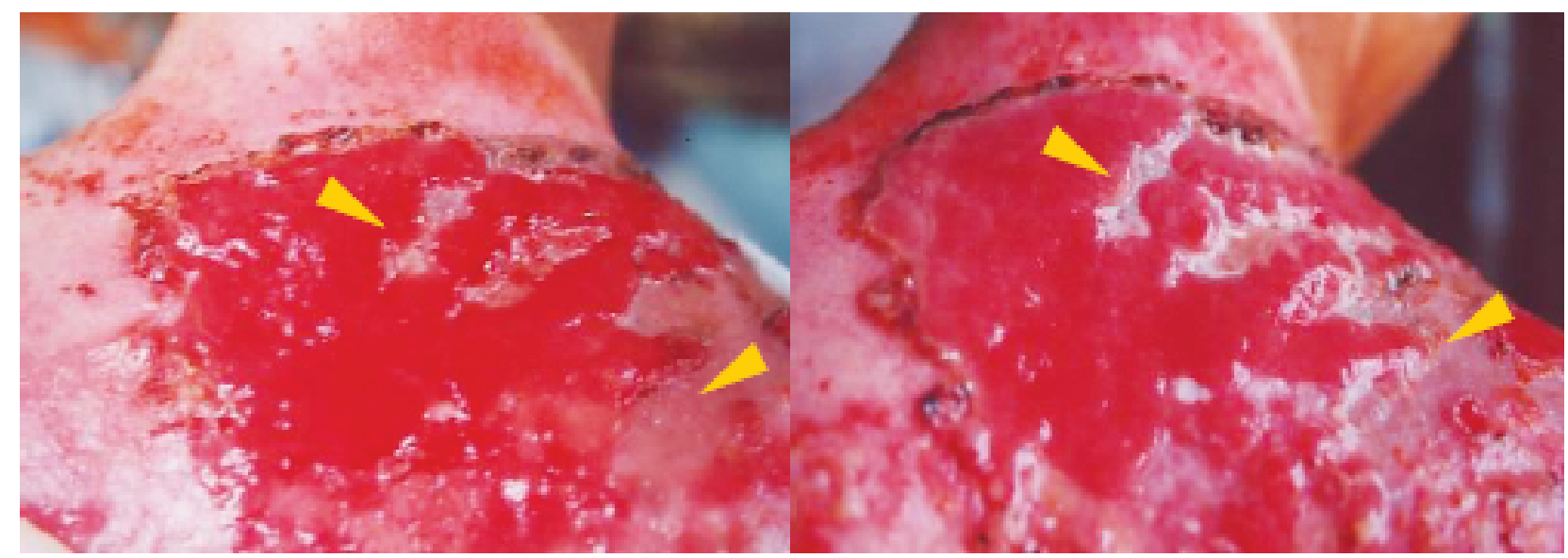

Figure 7. Subject with burn injury (flame) treated with SSD. On day 7 a minimal re-epithelialization (white shaded) was noted (left). No significant reduction of raw surface was noted on day 11 of the trial (right). 
In the end of study, it was observed that more subjects in the feracrylum group experienced less pain during change dressing compared to that of SSD group (Table 5). There were also more subjects in feracrylum group felt no pain at all compared to that of SSD group, though such difference was not statistically significant due to such small statistical power. This trend toward feracrylum is also in line with the clinical study conducted by Patel, et.al. ${ }^{24}$ that showed a significantly smaller number of patients in feracrylum group $(8.9 \%$ of study subjects) who experienced pain during change dressing, as compared to that of SSD group (75.5\%). This is of great importance as the patients may be convinced in choosing medication which does not induce pain on its application; and the use of feracrylum was proven to be more comfortable.

One subject developed fatal complication due to the subject's severe burn condition, which was then resulted in death. Such adverse event was not related with the investigational drug, however. There was an increment of platelet counts in all of the remaining subjects on day 7 , this was due to the haemostatic changes in the process of inflammation, where platelets plays an important role and such increases referred to the body's response to injury. This significant increment of platelet was not accounted as an adverse event.

A confirmative conclusion could not yet be withdrawn from this study due to the small statistical power. However, the result indicates that feracrylum was safe and well-tolerated in subjects with deep partial thickness (deep second degree) burn. From efficacy point of view, feracrylum solution $1 \%$ showed a clinically significant benefit over the SSD in re-epithelialization of deep partial thickness (deep second degree) burn. Yet, further larger study is needed to corroborate both statistically and clinically significant benefits of feracrylum in the treatment of deep partial thickness (deep second degree) burn as compared to SSD.

\section{Acknowledgements}

The study was supported by PT. Dexa Medica, Indonesia. The assistance of Eleanora Betha Anggiara, Ssi, Apt. (PT. Dexa Medica) in the statistical analysis of the results of the study and Liana W. Susanto, M. Biomed and Eleanora Betha Anggiara Ssi, Apt. in the preparation of writing the study report as well as this paper are gratefully acknowledged. We also highly appreciate the physicians and center involved in this study, particularly:
1. Alifa Dimanti, dr

2. Nursing staff of Burn Unit RSCM.

\section{REFERENCES}

1. Kao CC, Garner WL. Acute Burns. J Plast and Recon Surg 2000;105:2482-2493

2. Arturson G. Pathophysiology of the burn wound and pharmacological treatment: Burns 1996; 21 (4): 255-274

3. Peterson HD. Topical antibacterial. In: Boswick JA. The art and science of burn care. An Aspen Publication: 1987; p. 181-187.

4. Schwarz K, Dulchavsky S. Burn Wound Infections. Available in website: www.emedicine.com/MED/topic258. htm. Last Updated: March 15, 2002

5. Drosou A, Falabella A, Kirsner RS. Antiseptics on wounds: An area of controversy. Wounds. Available in website: www.medscape.com/viewpublication/102 . assessed on: March 15, 2002

6. Demling, RH, DeSanti, RN. What are the biologic properties of Silver related to wound infection control and healing http://www.burnsurgery.org .assessed on: July, 17, 2007

7. Physical \& Theoretical Chemistry Lab. Safety. Safety data (MSDS) for silver sulfadiazine. Available in website: $\underline{\mathrm{http}: / /}$ ptcl.chem.ox.ac.uk/MSDS/. assessed on: March 15, 2002

8. Demling RH, DeSanti RN. Effects of the silver on wound management. Wounds. Vol 13 No 1. Suppl. A. Jan-Feb 2001; 5-15.

9. Ringold DJ, Santell JP, Schneider PJ. ASHP national survey of pharmacy practice in acute care settings: dispensing and administration-1999. Am J Health Syst Pharm. 2000 Oct 1; 57(19):1759-75.

10. Snelling CF, Ronald AR, Waters WR, Yaworski DS, et al. Comparison of silver sulfadiazine and gentamicyn for topical prophylaxis against burn wound sepsis. Canad Med Ass J, 1978; Vol 119, Issue 5 466-470

11. Jarrett F, Ellerbe S, Demling R. Acute leukopenia during topical burn therapy with silver sulfadiazine. Am J Surg. 1978 Jun; 135(6):818-9.

12. Caffee HH, Bingham HG. Leukopenia and silver sulfadiazine. J Trauma. 1982 Jul; 22(7):586-7.

13. Moldawer LL, Minter RM, Rectenwald III JE. Emerging evidence of a more complex role for pro-inflammatory and anti-inflammatory cytokines in the sepsis response. In: Baue AE, Faist E, Fry DE. Multiple organ failure: Pathophysiology, prevention and therapy. Springer: 2000; p: 150

14. Bhagwat AM, Save S, Burli S, Karki SG. A Study to Evaluate the Antimicrobial Activity of Feracrylum and its Comparison with Povidone-Iodine. Indian J. Pathol. Microbial. 2001; 44(4): 431-433.

15. Eldad A, Icekson M, Zur T, Slosser D, et al. Silversulfadiazine eschar pigmentation mimics invasive wound infection: A case report. J Burn Care \& Rehab 2003; 24(3):154-157

16. Enoch S, Harding K. Wound bed preparation: The science behind the removal of barriers to healing. Health management publications, Inc. Wounds 15(7):213-229, 2003. 
17. Sze-Wee Ang E, Seng-Teik Lee, Siew-Gek Gan C, GimJiun See P, et al. Evaluating the role of alternative therapy in burn wound management: Randomized trial comparing moist exposed burn ointment with conventional methods in the management of patients with second-degree burns. Medscape general medicine 3(1), 2001

18. Sibbald RG. Et al. Preparing the wound bed - debridement, bacterial balance, and moisture balance. Ostomy/wound management 2000;46(11):14-35

19. Kirsner RS, Orsled H, Wright JB. Matrix metalloproteinases in normal and impaired wound healing: the potential role of nanocrystalline silver. Wound: 3 2002; 3:1-12.

20. Staiano-Coico L, Et al. Wound fluids: A reflection of the state of healing. Ostomy/Wound management 2000;46(Suppl 1A);85S-93S

21. Demling RH, DeSanti LRN. Closure of partial-thickness facial burns with a bioactive skin substitute in the major burn population decreases the cost of care and improves outcome. Wounds 14(6):230-234, 2002.
22. Wright JB, Kan Lam BS, Olson ME, Burrell RE. Is antimicrobial efficacy sufficient? A question concerning the benefits of new dressings. Wounds 15(5):133-142, 2003.

23. Darmansyah I, Setiawati A, Setiabudy R, Utama H. Guidelines on the conduct of clinical trials by GCP, PUKO Clinical trial center, Faculty of Medicine University of Indonesia - dr Cipto Mangunkusumo Hospital, $1^{\text {st }}$ ed. 1996

24. Patel P, Dharap S, Abhyankar SV. Clinical Evaluation of Efficacy and Safety of SEPGARD Gel (Feracrylum 1\% $\mathrm{w} / \mathrm{w})$ in dressing of Burn and Lacerated Wounds vis-àvis Wokadine (Povidone Iodine 5\%) ointment. Themis Medicare Limited, Mumbai. Unpublished clinical study final report.

25. Fox CL, Modak SM. Mechanism of Silver Sulfadiazine Action on Burn Wound Infections. Antimicrobial Agents and Chemotherapy, 1974; 5(6): 582-588

26. Herbert S, Rosenkranz, Carr HS. Sliver Sulfadiazine: Effect on the Growth and Metabolism of Bacteria. Antimicrobial Agents and Chemotherapy, 1972; 2(5): 367-372. 